\title{
The Flexibility of Temporary Employment in Europe
}

\author{
Margarida Rodrigues \\ University of Beira Interior, Covilhã, Portugal
}

mmmrodrigues@sapo.pt

Cidália Oliveira

NIPE (Center of Research in Economics and Management)

University of Minho, Braga, Portugal

\section{Rui Silva}

CETRAD (Center of Transdisciplinary Development Studies)

University of Trás-os-Montes e Alto Douro, Portungal

ruisilva@utad.pt

\begin{abstract}
Temporary employment is not influenced by the unemployment rate, but shows a positive relation with the social protection expenses of the companies. Poland is the country with the highest percentage of temporary workers (2013). The objective of this research is to study this flexibility, by obtaining empirical evidence in the European Union, using a quantitative research method. Research is still missing towards a better understanding of the relation between temporary employment and unemployment. The relevance of understanding of the effects of temporary employment in the European Labor Market. As future research, it is suggested that this study be replicated for the time span of 2006 to 2020. This research focuses on the geographical area studied, providing a better understanding of the relation between temporary employment and unemployment. This research is based on quantitative research using a European Union secondary database (Eurostat).
\end{abstract}

Keywords: European Union, Employment, Social Protection Expenses, Temporary employment and Unemployment

\section{Introduction}

Global economic transformation and financial crises increase job insecurity, employee's vulnerability and even the social risk of exclusion [1], [2]. Thus, temporary work agencies have addressed this vulnerability, because the vast majority of people have failed to ensure a permanent and secure job, and are continuously unemployed [3]. As it can be seen, the use of the temporary work force was promoted by the globalization phenomena, and its implications in institutional and organizational environments have been widely studied [4].

Work flexibility can provide, through the temporality of their workers, more flexible human resources structures [5], allowing for the reduction of their labour costs 
[6]. Thus, this flexibility is understood as the capacity of the companies to use temporary employees as a valid work force [7].

Regarding the theoretical framework, the choice was based on the resource-based view, in which the company is seen as a set of tangible and intangible resources [8][11]. Teece, Pisano, \& Shuen [12] state that there are three aspects essential to the dynamic configuration of resources and competences. The first aspect is related to sensing features of individual capacities of organizational process, to collect information through a scan of the market in order to discover new opportunities. The following is concerning seizing, it refers to adapting products to needs, according to a product and architecture selection, within the scope of a business model. Finally, reconfiguring is also of great interest, since it characterizes the possibility of transforming resources and skills, according to the needs of customers, based on specialization and knowledge management. Dynamic capabilities support new challenges and protect knowledge, achieving a competitive advantage [12], [13]. Due to the need for constant adaptation, dynamic capabilities are organizational indicators based on resources, with the goal of competitiveness, since without the support of dynamic capabilities, organizations regress in their competitive advantage [14]. These capacities reflect the potential of the organization in integrating, creating, reconfiguring internal and external competences, in order to correspond to market fluctuations [12]. Eisenhardt \& Martin [15] report, that the primary value of dynamic capabilities is not linked to capabilities per se, but to resource configuration. It is the configuration of resources and skills that will allow them to have a dynamic characterization. These stand out in highly dynamic markets, as they aspire to advantage in an unpredictable scenario, which requires that they exceed the characteristics of the resource-based theory, named RBV [16], [17].

Despite a significant number of research topics in this area, the literature on the link between the evolution of temporary work and total unemployment is limited, thus this research gap was identified for the present study. Total employment and social expenditure in the 28 member-European Union [18], lead countries to make deep reforms in their labour markets due to the financial crisis (2008), which, among others, created high rates of unemployment. In view of the above, the aim of this article is to analyse the relationship between job flexibility and unemployment, employment and associated social expenditure, in the European context in the year 2013. In this context, the following research question is raised: What influence do unemployment rates, employment rates and social protection expenses have on temporary work (European context)?

\section{Literature Review}

Given the complexity of the labour market, there has been a decrease in stable/permanent jobs in favour of other forms of employment, with greater contractual flexibility, working hours and more quantitative benefits to the employer, as is the case of temporary work [19]. To this author, in the world context, where the financial logic and short-term income continue to be predominant, there is an incessant pressure for a greater flexibility of the labour market, as companies want a 
workforce that responds quickly, easily and at a low cost to market fluctuations. Due to these constant changes, the adaption to the market's requirements are crucial [12], [20], [21].

Thus, in the recent decades, and in numerous countries, there has been a significant increase in the number of temporary workers, reflecting an increased competition between companies and markets (globalization), which implied that they had to adapt swiftly to the changes in the conditions of supply and demand [22]. On the other hand, the global economic recession caused by the 2008 crisis also reduced the bargaining power of workers and their opportunities to continue to have permanent jobs, and in the countries where there was some recovery in employment, this focused on the temporary employment, the same authors concluded.

In view of the above, in the last decades, the increase of temporary work has been a response to high unemployment in many countries, however the legal framework differs from country to country [23]-[25]. Kovacs [19] argued that there was empirical evidence that flexible work has been increasing all over Europe, despite the subsistence of differences among countries. This type of job has been considered to be the main way for unemployed people (e.g. women, young people and people with low qualifications) to enter working life, that is, the labour market [19], [26]. These temporary jobs, with short-term contracts, can act as a springboard to better paid employment or be a vehicle of transition between school and employment [27]. Also Kyyrä [28] said that the option of the individuals for this form of employment is, to an extent, involuntary because of the difficulty in getting a better job in some countries

In short, temporary work can be the vehicle for regular employment [29], $[30][31]$, [32], as well as a way to reduce the unemployment rate, if competent entities set social security programs with benefits for the employer and the employee [33].

Costa [34] argued that it is only possible to create more jobs for people through flexible labour legislation and working conditions (e.g., Socials). De Graaf-Zijl et al. [30] so as recently Caroleo, Rocca, Mazzocchi, Quintano [35] concluded that there is a growing trend of temporary work in many countries and there is a broad debate about the benefits of this type of job in relation to the unemployment numbers. It means that if a temporary worker gets a permanent job, they will have the possibility of obtaining a higher remuneration than when they were effectively unemployed, explained these authors. Pulignano \& Doerflinger [36] considered that this type of work can be seen as a protection for the maintenance of permanent jobs, especially in situations of economic crisis. On the other hand, the dispersed legislation about labour relations in the labour market has contributed to contractual flexibility, where companies have the option of having seasonal workers [7]. These authors argued that this seasonality brings benefits for the companies both in terms of fixed costs and future burdens of eventual redundancies. According to Chen and Funke [37] a rigid labour legislation may increase the demand for temporary workers, but although there are different legislative frameworks, they follow the recommendations of the European Union [38]. Also, many of the people who use temporary work have low or medium skillsand as such are seeking short-term jobs, allowing subcontractors to have minor expenses [39]. This means that temporary work companies reduce the labour costs of contracting companies, since they are the first to support wages and taxes, 
and there are even some companies that provide adequate training for contracted employees [40]. The growing demand for this form of employment by companies is largely related to the need to reduce their labour costs, since these labour contracts are flexible [19].

As it turns out, the use of temporary workforce has become a global phenomenon, so researchers have a growing interest in the implications of its use around the world [38]. An organization can better manage its human resources this way because of its flexible human resource structure [5]. In addition, organizations seek a temporary workforce to reduce their labour costs [6], [41], so resorting to temporary agencies is a way to achieve this reduction. In this context, temporary work can contribute to improving the enterprises' economic performance by allowing them to reduce fixed labour costs (such as social protection) associated with permanent workers [42]-[45] and also to solve the work cycles recessions depending on the market [44], [46]. From another point of view, Osuna and García-Pérez [47] argued that temporary work does not necessarily reduce the unemployment rate, since this reduction is related to the level of social expenses that companies have to bear towards the type of contractual relationship with the worker. Also to Kopycińska and Kryńska [44], measures must be taken to strengthen the temporary workers' social protection and the wage balance must prevail regardless of the type of contractual relationship, among others.

The exposure to global competition, the volatility of the demand and supply law, the development of new production processes and the current degree of uncertainty are relevant factors [49]-[51]. Consequently, there is the need of flexible employment contracts from the point of view of the employer companies, once they always seek a strategy of efficiency [52]. Of course this situation has resulted in the segmentation of the labour market, originated by a wide institutional negotiation process around the world [52]. In the last decades, many economists have argued repeatedly that Europe's high unemployment rate should be reduced by making labour markets more flexible [53], in particular by introducing efficient education mechanisms to enable continuous and dynamic learning, which may lead to better wage conditions and a strong protection against lay-off. Thus, all over Europe, there is a duality of the labour market, which contrasts being employed to being unemployed, but in between the two there is temporary work in the middle of which comes the temporary work with lower rights, less protection, but leads to the reduction of social expenses of the companies [54]. These authors pointed out that the regulations of this type of work in Europe aim to fight the high unemployment and to maintain the competitiveness of companies. In particular, with regard to western Europe, the researchers identified an increase in temporary work from the 80 s and in the middle of the 90 s they noticed a significant positive evolution [38], e.g., in the 90s, Spain suffered a high demand for temporary workers by companies, reaching one third of the workers in its business fabric. Specifically, Koene and Ansari [55] argued that the appearance of a new labour market in Spain was sustained by institutional changes. According to these authors, temporary work was legalized in Spain in 1994, in the context of wide institutional reforms implemented in this market that aimed to construct a long term sustainable labour market. These authors argued that temporary work has grown quickly in Spain since the middle of the 80 sbecause in the previous periodits legislation was strict in 
the protection of employment. However, the growing internationalization of the economy and the economic crisis helped to trigger market reforms in 1984, which were directed towards flexibility and temporary contracts [56]. Thereby, Spain developed a dual labour market in the early 90s, where protectionism for permanent jobs coexisted with low-quality temporary labour with little protection. In Spain, there is a high percentage of temporary workers because the relevant legislation is more flexible and less bureaucratic, as a way to avoid an increase in the rate of job destruction [47].

Thus, based on the literature review conducted, the following research hypothesis arise.

Hypothesis 1: Unemployment leads to Temporary work.

Hypothesis 2: Employment may be increased by Temporary work.

Hypothesis 3: Temporary work has a positive relation with companies' social expenses.

Hypothesis 4: Spain is the European country with the largest number of temporary workers.

\section{Research methodology}

The research method used was quantitative research using a European Union secondary database (Eurostat) which provides a variety of statistical information on the member countries of the European Union- In this study, only data related to population and social conditions will be taken into account.

Table 1 presents a summary of the methodology and Table 2 the essential aspects considered.

\begin{tabular}{|l|l|}
\hline $\begin{array}{l}\text { Research planning (introduction } \\
\text { and review of the literature) }\end{array}$ & $\begin{array}{l}\text { Definition of the subject to be investigated and its } \\
\text { framework in terms of literature review. }\end{array}$ \\
\hline Data collection and preparation & $\begin{array}{l}\text { Identification of the database to be used, compilation and } \\
\text { harmonization of the data, to be comparable and subject to } \\
\text { statistical analysis. }\end{array}$ \\
\hline Data analysis & $\begin{array}{l}\text { Identification of the statistical techniques to be used and the } \\
\text { interpretation and discussion of results, according to } \\
\text { Marôco (2014); Pestana \& Gageiro (2014) }\end{array}$ \\
\hline
\end{tabular}

Table 1. Structure of the methodology

\begin{tabular}{|l|l|}
\hline \multicolumn{1}{|c|}{ Unit of analysis } & \multicolumn{1}{c|}{ Countries } \\
\hline Research countries & 28 European Union countries \\
\hline Geographical area & Europe \\
\hline Data collection & Eurostat secondary data - Population and Social Conditions \\
\hline Analysis period & 2013 \\
\hline Quantitative software & IBM SPSS Statistic (version 24) \\
\hline Data analysis & This analysis is divided into two distinct parts: \\
\hline
\end{tabular}




\begin{tabular}{|l|l|}
\hline & $\begin{array}{l}\text { Descriptive statistics (tables and graphs) } \\
\text { Construction of } 4 \text { regression models, until a model with } \\
\text { statistically significant independent variables was obtained, } \\
\text { to conclude on the previously defined research hypothesis } \\
(1,2,3) . \text { Research hypothesis } 4 \text { is analysed with descriptive } \\
\text { statistics only. }\end{array}$ \\
\hline
\end{tabular}

Table 2. Essential aspects followed

\section{Presentation and Discussion of Results}

In order to make a statistical treatment of the obtained raw data, a harmonization of the data was made. In other words, in order to be able to use the regression model, the data from different dimension countries, the absolute data relative to the number of employees, unemployed and temporary employees had to be put in perspective, so the active population was used, calculating the \% values of employees, unemployed and temporary employees by the active population. Note that the global data from Europe are only presented for comparative purposes with other countries' data, once only data from 28 countries will be used in the regression. Data on the unemployed are for a wider age range, between 15 and 74 years old, in contrast to the remaining, that are for an age range between 15 and 64 years old. However, this approach had to be used, since there was no other information regarding the unemployed in the data base.

\begin{tabular}{|l|c|c|c|c|}
\hline \multicolumn{1}{|c|}{ Country } & $\begin{array}{c}\text { \% Temporary } \\
\text { Employees }\end{array}$ & $\begin{array}{c}\text { \% } \\
\text { Unemployed }\end{array}$ & $\begin{array}{c}\text { \% } \\
\text { Employees }\end{array}$ & $\begin{array}{c}\text { Social Protection } \\
\text { Expenses }\end{array}$ \\
\hline European Union (28 countries) & $10,20 \%$ & $11,03 \%$ & $89,01 \%$ & $7.416,10$ \\
\hline European Union (27 countries) & $10,20 \%$ & $10,98 \%$ & $89,06 \%$ & $7.460,33$ \\
\hline European Union (15 countries) & $10,26 \%$ & $11,22 \%$ & $88,82 \%$ & $8.853,25$ \\
\hline Euro area (19 countries) & $11,08 \%$ & $12,13 \%$ & $87,91 \%$ & $8.348,87$ \\
\hline Euro area (18 countries) & $11,16 \%$ & $12,13 \%$ & $87,91 \%$ & $8.407,71$ \\
\hline Euro area (17 countries) & $11,21 \%$ & $12,13 \%$ & $87,91 \%$ & $8.448,97$ \\
\hline Belgium & $6,35 \%$ & $8,50 \%$ & $91,51 \%$ & $10.116,40$ \\
\hline Bulgaria & $4,30 \%$ & $13,13 \%$ & $86,94 \%$ & 979,19 \\
\hline Czech Republic & $7,00 \%$ & $7,08 \%$ & $92,96 \%$ & $2.936,85$ \\
\hline Denmark & $7,50 \%$ & $7,16 \%$ & $92,85 \%$ & $14.425,99$ \\
\hline Germany & $11,33 \%$ & $5,35 \%$ & $94,67 \%$ & $9.715,54$ \\
\hline Estonia & $2,90 \%$ & $8,96 \%$ & $91,15 \%$ & $2.106,85$ \\
\hline Ireland & $7,19 \%$ & $13,38 \%$ & $86,68 \%$ & $8.084,11$ \\
\hline Greece & $4,67 \%$ & $27,81 \%$ & $72,30 \%$ & $4.291,27$ \\
\hline Spain & $14,09 \%$ & $26,26 \%$ & $73,78 \%$ & $5.567,60$ \\
\hline
\end{tabular}




\begin{tabular}{|l|c|c|c|c|}
\hline France & $12,28 \%$ & $10,00 \%$ & $90,03 \%$ & $10.262,71$ \\
\hline Croatia & $9,94 \%$ & $17,54 \%$ & $82,50 \%$ & $2.199,65$ \\
\hline Italy & $8,82 \%$ & $12,37 \%$ & $87,67 \%$ & $7.633,22$ \\
\hline Cyprus & $12,31 \%$ & $16,21 \%$ & $84,00 \%$ & $4.650,19$ \\
\hline Latvia & $3,36 \%$ & $12,21 \%$ & $87,93 \%$ & $1.631,94$ \\
\hline Lithuania & $2,08 \%$ & $12,01 \%$ & $88,02 \%$ & $1.708,34$ \\
\hline Luxembourg & $6,02 \%$ & $5,90 \%$ & $94,02 \%$ & $19.442,71$ \\
\hline Hungary & $8,74 \%$ & $10,26 \%$ & $89,77 \%$ & $2.113,56$ \\
\hline Malta & $6,05 \%$ & $6,49 \%$ & $93,51 \%$ & $3.372,81$ \\
\hline Netherlands & $15,73 \%$ & $7,40 \%$ & $92,70 \%$ & $11.333,50$ \\
\hline Austria & $7,66 \%$ & $5,43 \%$ & $94,58 \%$ & $11.011,37$ \\
\hline Poland & $18,87 \%$ & $10,48 \%$ & $89,54 \%$ & $1.966,04$ \\
\hline Portugal & $14,60 \%$ & $17,07 \%$ & $82,99 \%$ & $4.243,66$ \\
\hline Romania & $0,93 \%$ & $7,39 \%$ & $92,61 \%$ & $1.050,67$ \\
\hline Slovenia & $12,33 \%$ & $10,28 \%$ & $89,70 \%$ & $4.275,88$ \\
\hline Slovakia & $4,94 \%$ & $14,28 \%$ & $85,76 \%$ & $2.435,89$ \\
\hline Finland & $12,28 \%$ & $8,36 \%$ & $91,65 \%$ & $11.338,88$ \\
\hline Sweden & $13,52 \%$ & $8,30 \%$ & $91,76 \%$ & $13.376,66$ \\
\hline United Kingdom & $4,78 \%$ & $7,78 \%$ & $92,29 \%$ & $8.859,72$ \\
\hline
\end{tabular}

Table 3. Relative data under analysis for the year 2013

In terms of descriptive statistics, for the quantitative variables in the study we present some relevant data - table 4 - and illustrative graphs of the values distribution in each variable, figures 1 to 4 .

\begin{tabular}{|l|c|c|c|c|c|c|}
\hline & N & Average & $\begin{array}{c}\text { Standard } \\
\text { deviation }\end{array}$ & $\begin{array}{c}\text { Coefficient } \\
\text { of variation }\end{array}$ & Minimum & Maximum \\
\hline \% Temporary employees & 28 & $8,59 \%$ & $4,55 \%$ & $53 \%$ & $0,93 \%$ & $18,87 \%$ \\
\hline \% Unemployed & 28 & $11,34 \%$ & $5,60 \%$ & $49 \%$ & $5,35 \%$ & $27,81 \%$ \\
\hline$\%$ Employed & 28 & $88,71 \%$ & $5,58 \%$ & $6 \%$ & $72,30 \%$ & $94,67 \%$ \\
\hline $\begin{array}{l}\text { Social protection expenses } \\
\text { (euros per capita) }\end{array}$ & 28 & 6468,97 & 4846,87 & $75 \%$ & 979,19 & 19442,71 \\
\hline
\end{tabular}

Table 4. Variables descriptive statistics

In the sample, the $\%$ of temporary employees presents an average value of $8.59 \%$, with a dispersion of values of $53 \%$. The minimum and maximum values are, respectively, $0.93 \%$ and $18.87 \%$. It can be observed that the distribution of values of 
the $\%$ of temporary employees mainly occurs between $2.5 \%$ and $15 \%$. In the sample, the $\%$ of unemployed presents an average value of $11.34 \%$, with a dispersion of values of $49 \%$. The minimum and maximum values are respectively $5.35 \%$ and $27.81 \%$. It can be observed that the distribution of values of the $\%$ of unemployed mainly occurs between $5 \%$ and $15 \%$, and while all values over $20 \%$ (for Greece and Spain) are outliers, extreme cases that go out of the distribution normal values. In the sample, the $\%$ of employees present an average value of $88.71 \%$, with a dispersion of values of $6 \%$. The minimum and maximum values are, respectively, $72.30 \%$ and $94.67 \%$. It can be observed that the distribution of values of \% of employees is mainly between $82.5 \%$ and $95 \%$, and while all values below $80 \%$ (for Greece and Spain) are outliers, extreme cases that go out of the normal distribution of values. In the sample, social protection expenses have an average value of $6468.97 €$, with a dispersion of values of $75 \%$. The minimum and maximum values are, respectively, $€ 979.19$ and $€$ $19.442,71$. Turning now to the multiple linear regression model, the following formula is given:

$$
Y_{n}=\beta_{0}+\beta_{1 X_{1}}+\beta_{2 X_{2}}+\beta_{3 X_{3}}+\varepsilon
$$

Thus, the dependent variable is the \% temporary employees $\left(Y_{n}\right)$ and the $\%$ employees $\left(X_{1}\right)$, the \% employees $\left(X_{2}\right)$ and the social protection expenses $\left(X_{3}\right)$ are the independent variables. $\mathrm{n}$ corresponds to the 28 countries of the European Union. Thus, the determination coefficients are shown in table 5.

\begin{tabular}{|c|c|c|c|c|}
\hline Model & $\mathbf{R}$ & R Square & Adjusted R Square & Std. Error of the Estimate \\
\hline 1 &, $339^{\mathrm{a}}$ &, 115 &, 004 & 4,53646 \\
\hline
\end{tabular}

Table 5. Model Summary Source: own elaboration

The coefficient of determination $r^{2}=0,115$ indicating that $11,5 \%$ of the variation occurs in the \% temporary employees is explained by the variables included in this model. The coefficient of determination adjusted $r_{a}^{2}=0,004$ is $0,4 \%$.

To determine if this model is globally significant, table 6 and 7 are presented.

\begin{tabular}{|l|l|c|c|c|c|c|}
\hline \multicolumn{2}{|c|}{ Model } & Sum of Squares & df & Mean Square & F & Sig. \\
\hline \multirow{2}{*}{1} & Regression & 63,931 & 3 & 21,310 & 1,036 & 0,395 \\
\cline { 2 - 7 } & Residual & 493,908 & 24 & 20,579 & & \\
\cline { 2 - 7 } & Total & 557,839 & 27 & & & \\
\hline
\end{tabular}

Table 6. ANOVA 
The F test, to the global significance of the model, is not validated because it presents a probative value higher than $5 \%(\mathrm{p}=0,395)$ which does not allow to reject the hypothesis.

\begin{tabular}{|c|c|c|c|c|c|c|}
\hline \multirow{2}{*}{\multicolumn{2}{|c|}{ Model }} & \multicolumn{2}{|c|}{$\begin{array}{l}\text { Unstandardized } \\
\text { Coefficients }\end{array}$} & \multirow{3}{*}{$\begin{array}{c}\text { Standardized } \\
\text { Coefficients }\end{array}$} & \multirow{3}{*}{$\frac{\mathbf{t}}{-, 678}$} & \multirow{3}{*}{$\begin{array}{r}\text { Sig. } \\
, 504\end{array}$} \\
\hline & & \multirow{2}{*}{$\frac{\text { B }}{-1042,333}$} & \multirow{2}{*}{$\begin{array}{c}\text { Std. Error } \\
1537,065\end{array}$} & & & \\
\hline 1 & (Constant) & & & & & \\
\hline & $\%$ Unemployed & 10,603 & 15,306 & 13,069 & 693 & ,495 \\
\hline & $\%$ Employee & 10,468 & 15,368 & 12,840 & ,681 & ,502 \\
\hline & Social protection expenses &, 000 &, 000 & ,346 & 1,641 &, 114 \\
\hline
\end{tabular}

Table 7. Variables' coefficients in the model and level of significance

The variables included in the model indicate that there are no significant variables for the model, that is, for the explanation of the dependent variable $\%$ temporary employees.

On the other hand, Pearson's correlation coefficient was applied to study the nature of the relationship between the dependent variable and the independent variables, and it was concluded that there are no statistically significant relationships between the dependent variable and the independent ones.

However, since this model includes 3 independent variables, tests were performed on the assumptions associated with it, that is, multicollinearity (Pearson's correlation matrix), in which it was concluded that there is multicollinearity between $\%$ unemployed and \% employees. In this context, since the violation of this assumption is so evident, it makes no sense to proceed with the analysis of this regression model.

Thus, a new regression model is presented without one of the variables that present a strong multicollinearity between them, being the variable $\%$ employees the excluded variable. Thus, the model only has as independent variables the \% unemployed and the social protection expenses (Table 8).

\begin{tabular}{|c|c|c|c|c|}
\hline Model & R & R Square & Adjusted R Square & $\begin{array}{c}\text { Std. Error of the } \\
\text { Estimate }\end{array}$ \\
\hline 1 &, $312^{\text {a }}$ &, 097 &, 025 & 4,48757 \\
\hline
\end{tabular}

Table 8. Model Summary

The determination coefficient $r^{2}=0,097$ indicating that $9,7 \%$ of the variation occurs in \% temporary employees is explained by the independent variables included in the model, having decreased relatively to the first model, since it presents an independent variable less. The adjusted determination coefficient $r_{a}{ }^{2}=0,025$ is $2,5 \%$, and has increased considerably, with respect to the first model, which indicates that 
this model is better, in explanatory terms, of the \% temporary employees. For the overall evaluation of the model, the following tests were performed (Tables 9 and 10).

\begin{tabular}{|c|l|c|c|c|c|c|}
\hline \multicolumn{2}{|c|}{ Model } & Sum of Squares & df & Mean Square & F & Sig. \\
\hline \multirow{2}{*}{1} & Regression & 54,383 & 2 & 27,191 & 1,350 &, $277^{\mathrm{b}}$ \\
\cline { 2 - 8 } & Residual & 503,456 & 25 & 20,138 & & \\
\cline { 2 - 8 } & Total & 557,839 & 27 & & & \\
\hline
\end{tabular}

Table 9. ANOVA

The F Test, to the model's global significance, is again not validated because it presents a test value higher than $5 \%(p=0,277)$.

\begin{tabular}{|c|c|c|c|c|c|c|}
\hline \multirow{2}{*}{\multicolumn{2}{|c|}{ Model }} & \multicolumn{2}{|c|}{$\begin{array}{l}\text { Unstandardized } \\
\text { Coefficients }\end{array}$} & \multirow{2}{*}{$\begin{array}{c}\begin{array}{c}\text { Standardized } \\
\text { Coefficients }\end{array} \\
\text { Beta } \\
\end{array}$} & \multirow[b]{2}{*}{$\mathbf{t}$} & \multirow[b]{2}{*}{ Sig. } \\
\hline & & B & Std. Error & & & \\
\hline \multirow[t]{3}{*}{1} & (Constant) & 4,629 & 2,762 & & 1,676 & , 106 \\
\hline & $\%$ Unemployed &, 178 &, 167 & ,219 & 1,069 & ,295 \\
\hline & Social Protection expenses & 000 &, 000 &, 320 & 1,560 &, 131 \\
\hline
\end{tabular}

Table 10. Coefficients of the variables and level of significance

The variables included in the model indicate that there are no significant variables for the model, that is, for the explanation of the percentage of temporary employees none of the two variables chosen for this new model are statistically significant for the explanation of the variation observed in the \% temporary employees.

In view of this result, standardized residues were analyzed, where Poland was identified as an outlier. From the analysis of the standardized residues, shown in the graph above, the detection of outliers allows us to identify as outlier the case corresponding to Poland.

The new model of regression integrates now the \% unemployed and the social protection expenses (Tables 11,12 and 13).

\begin{tabular}{|c|c|c|c|c|}
\hline Model & R & R Square & Adjusted R Square & $\begin{array}{c}\text { Std. Error of the } \\
\text { Estimate }\end{array}$ \\
\hline 1 &, $462^{\mathrm{a}}$ &, 214 &, 148 & 3,83012 \\
\hline
\end{tabular}

Table 11. Model Summary

The coefficient of determination $r^{2}=0.214$ indicates that $21.4 \%$ of the variation occurring in the \% temporary employees is explained by the two independent 
variables included in the model, having increased considerably compared to the previous model. The adjusted coefficient of determination $r_{a}^{2}=0.148$ is $14.8 \%$ also significantly increased in relation to the previous model, which indicates that this model is better in terms of the \% temporary employees.

\begin{tabular}{|c|l|c|c|c|c|c|}
\hline \multicolumn{2}{|c|}{ Model } & Sum of Squares & df & Mean Square & F & Sig. \\
\hline \multirow{2}{*}{1} & Regression & 95,592 & 2 & 47,796 & 3,258 &, $056^{\mathrm{b}}$ \\
\cline { 2 - 8 } & Residual & 352,075 & 24 & 14,670 & & \\
\cline { 2 - 8 } & Total & 447,667 & 26 & & & \\
\hline
\end{tabular}

a. Dependent Variable: \% temporary employees b. Predictors: (Constant), social protection expenses, $\%$ unemployed

Table 12. ANOVA

The $\mathrm{F}$ test, to the global significance of the model, remains uncorrected because it presented a test value higher than $5 \%(\mathrm{p}=0.056)$.

\begin{tabular}{|c|c|c|c|c|c|c|}
\hline \multirow{2}{*}{\multicolumn{2}{|c|}{ Model }} & \multicolumn{2}{|c|}{ Unstandardized Coefficients } & \multirow{2}{*}{$\begin{array}{c}\text { Std. Coefficients } \\
\text { Beta }\end{array}$} & \multirow[b]{2}{*}{ t } & \multirow[b]{2}{*}{ Sig. } \\
\hline & & B & Std. Error & & & \\
\hline \multirow[t]{3}{*}{1} & (Constant) & 2,878 & 2,419 & & 1,189 & ,246 \\
\hline & $\%$ Unemployed & ,228 & ,143 & ,313 & 1,593 &, 124 \\
\hline & $\begin{array}{l}\text { Social Protection } \\
\text { expenses }\end{array}$ &, 000 &, 000 & ,484 & 2,459 &, 022 \\
\hline
\end{tabular}

Table 13. Coefficients of the variables and level of significance

It is concluded that the percentage of temporary employees increases significantly with the increase of social protection expenses. Also in this model, multicollinearity, the normal distribution of residues and the assumption of homoscedasticity were absent. In order to better understand the effects of multicollinearity, we present a regression model with \% employees and social protection expenses, without Poland (Tables 14,15 and 16).

\begin{tabular}{|c|c|c|c|c|}
\hline Model & R & R Square & Adjusted R Square & $\begin{array}{c}\text { Std. Error of the } \\
\text { Estimate }\end{array}$ \\
\hline 1 &, $460^{\mathrm{a}}$ &, 212 &, 146 & 3,83420 \\
\hline
\end{tabular}

a. Predictors: (Constant), social protection expenses, \% employees b. Dependent Variable: \% temporary employees

Table 14. Model Summary

The determination coefficient $r^{2}=0,212$ indicates that $21,2 \%$ of the variation occurring in the \% temporary employees is explained by the two independent 
variables included in the model, similar to the previous model. The adjusted determination coefficient $\mathrm{r}_{\mathrm{a}}{ }^{2}=0,146$ is $14,6 \%$ and is also similar to that of the previous model, which indicates that the latter two models are similar in explanatory terms of the $\%$ temporary employees.

\begin{tabular}{|c|l|c|c|c|c|c|}
\hline \multicolumn{2}{|c|}{ Model } & Sum of Squares & df & Mean Square & F & Sig. \\
\hline \multirow{2}{*}{1} & Regression & 94,840 & 2 & 47,420 & 3,226 &, $057^{\mathrm{b}}$ \\
\cline { 2 - 8 } & Residual & 352,827 & 24 & 14,701 & & \\
\cline { 2 - 8 } & Total & 447,667 & 26 & & & \\
\hline
\end{tabular}

a. Dependent Variable: \% temporary employees b. Predictors: (Constant), social protection expenses, $\%$ employees

Table 15. ANOVA

The F Test, to t the global significance of the model, remains not validated, as it presents a test value higher than $5 \%(\mathrm{p}=0,057)$.

\begin{tabular}{|c|c|c|c|c|c|c|}
\hline \multirow{2}{*}{\multicolumn{2}{|c|}{ Model }} & \multicolumn{2}{|c|}{$\begin{array}{l}\text { Unstandardized } \\
\text { Coefficients }\end{array}$} & \multirow{2}{*}{$\begin{array}{c}\begin{array}{c}\text { Standardized } \\
\text { Coefficients }\end{array} \\
\text { Beta }\end{array}$} & \multirow[b]{2}{*}{$\mathbf{t}$} & \multirow[b]{2}{*}{ Sig } \\
\hline & & B & Std. Error & & & \\
\hline \multirow[t]{3}{*}{1} & (Constant) & 25,554 & 12,376 & & 2,065 &, 050 \\
\hline & $\%$ employees &,- 226 & ,144 &,- 310 & 1,575 & ,128 \\
\hline & Social protection expenses &, 000 &, 000 & ,482 & 2,449 &, 022 \\
\hline
\end{tabular}

Table 16. Coefficients of the variables and level of significance

It can be concluded that the \% temporary employees increases significantly with the rise in social protection expenses. For the $\%$ employees, the results are inverse to those of the previous model to the \% unemployed, since the relation between these is inversely proportional. In this model, all standardized residues are now within desirable limits, so there is no outlier in this new model. We also verify the absence of the multicollinearity assumption, the normal distribution of residues and the homoscedasticity assumption.

Finally, by the application of the Backward method and the Pearson correlation, it can be concluded that between the $\%$ temporary employees and the $\%$ unemployed and the $\%$ employed and the social protection expenses there are no statistically significant relationships in an isolated way.

Regarding the comparison of the results with the literature review for each of the defined research hypothesis, we conclude that:

Hypothesis 1: Unemployment leads to Temporary work

This hypothesis is not confirmed, as there is no significant correlation between the $\%$ of unemployed and the percentage of temporary employees in any of the presented models, more specifically in the final model, that is, the $1 \%$ increase in the 
$\%$ unemployed causes an average increase of the \% temporary employees of B = 0.228 , however, this relation is not statistically significant $(\mathrm{p}=0.124)$ (table 13). The non-verification of this hypothesis contradicts the arguments that temporary employment would be a half or one influential factor in reducing unemployment.

Hypothesis 2: Employment may be increased by Temporary work

This hypothesis is not confirmed, as there is no significant correlation between the $\%$ unemployed and the percentage of temporary employees in any model, in particular in the final model, that is, the $1 \%$ increase in the $\%$ unemployed causes an average decrease of the \% temporary employees of $\mathrm{B}=-0.226$, however, the relationship is not statistically significant $(\mathrm{p}=0.128)$ (table 16). In addition, there is no significant relationship between the \% employees and the percentage of temporary employees because the relationship that occurs even has a negative signal, which contradicts the hypothesis presented. Although some authors consider temporary employment as a means to increase employment [19], [26]-[28], this was not the case. For Osuna \& García-Pérez [47] the reduction of the unemployment rate is more related to the cost of social expenses to be borne by companies. This type of employment will only have positive effects on unemployment if there is less rigid legislation and labour markets [34], [59].

Hypothesis 3: Temporary work has a positive relationship with social expenses of companies.

This hypothesis is verified for the final model developed, since there is a significant correlation between social protection expenses and the $\%$ temporary employees, where the increase of one euro in social protection expenses per inhabitant causes an average increase of the $\%$ temporary employees of $\mathrm{B}=0.000413$, the ratio being statistically significant $(\mathrm{p}=0.0022)$ (table 16). Therefore, we can affirm that for each increase of 1,000 euros in social protection expenses per capita, the percentage of temporary employees increases by 0.413 percentage points, on average, as we can see in hypothesis 3 . This positive relation is corroborated by several authors [39], who showed that this type of employment allows for the reduction of human resources and the lower rigidity of the structure [5]. On the other hand, this positivity can improve the financial performance of companies, especially in times of recession/economic crisis [42], [48], [60].

Hypothesis 4: Spain is the European country with the largest number of temporary workers

\begin{tabular}{|l|c|}
\hline Country & $\begin{array}{c}\text { \% Temporary } \\
\text { employees }\end{array}$ \\
\hline Poland & $18,87 \%$ \\
\hline Netherlands & $15,73 \%$ \\
\hline Portugal & $14,60 \%$ \\
\hline Spain & $14,09 \%$ \\
\hline Sweden & $13,52 \%$ \\
\hline
\end{tabular}




\begin{tabular}{|l|c|}
\hline Slovenia & $12,33 \%$ \\
\hline Cyprus & $12,31 \%$ \\
\hline France & $12,28 \%$ \\
\hline Finland & $12,28 \%$ \\
\hline Germany & $11,33 \%$ \\
\hline Croatia & $9,94 \%$ \\
\hline Italy & $8,82 \%$ \\
\hline Hungary & $8,74 \%$ \\
\hline Austria & $7,66 \%$ \\
\hline Denmark & $7,50 \%$ \\
\hline Ireland & $7,19 \%$ \\
\hline Czech Republic & $7,00 \%$ \\
\hline Belgium & $6,35 \%$ \\
\hline Malta & $6,05 \%$ \\
\hline Luxembourg & $6,02 \%$ \\
\hline Slovakia & $4,94 \%$ \\
\hline United Kingdom & $4,78 \%$ \\
\hline Greece & $4,67 \%$ \\
\hline Bulgaria & $2,30 \%$ \\
\hline Latvia & $36 \%$ \\
\hline Estonia & \\
\hline Lithuania & $2,93 \%$ \\
\hline Romania & $7,3 \%$ \\
\hline
\end{tabular}

Table 17. Relative data in analysis, for the year 2013

This hypothesis is not verified either, since the country with the highest percentage of temporary employees in 2013 is Poland with $18,87 \%$, contrary to what Osuna \& García-Pérez [47] argue. Below, we have a summary table of the Hypotheses of this Research, with their Status (table 18):

\begin{tabular}{|c|c|}
\hline Hypothesis & Results \\
\hline $\mathbf{1}$ & Not confirmed \\
\hline $\mathbf{2}$ & Not confirmed \\
\hline $\mathbf{3}$ & confirmed \\
\hline $\mathbf{4}$ & Not confirmed \\
\hline
\end{tabular}

Table 18. Final Results 


\section{Conclusions}

In line with the research question, we can conclude that the increase of temporary employment in the European Union has not achieved the desired performance in terms of reducing unemployment and, inherently, increasing employment. However, it has been found that this increase is related to companies' aim to reduce their fixed costs with human resources and to make their structure less rigid being an effective way to improve financial performance. On the other hand, in the analysed period, Poland has more temporary employees than Spain.

Considering the limitations of this study, it might be considered that the analysed timespan should be improved, in further studies, as the used database only allows for the timespan from 2014 to 2015 of the 28 members of the European Union.

The contributions of this article are related to the scope of the geographical area studied, as most of the research focuses on a specific geographic context, furthermore it provides a better understanding of the relation between temporary employment and unemployment.

For future research, we suggest the replication of this study for the time period 2006-2015, which would provide comprehensive and relevant empirical evidence for a longer time span. Furthermore, it would be relevant to understand the reasons why Poland is the country with the highest $\%$ of temporary employees.

Funding: This paper is financed by National Funds of the FCT - Portuguese Foundation for Science and Technology within the project «UIDB/03182/2020 and UIDB/04011/2020.

Acknowledgments: The authors gratefully acknowledge the technical support received from NIPE (Centre for Research in Economics and Management), University of Minho and CETRAD (Centre for Transdisciplinary Development Studies), University of Trás-os-Montes e Alto Douro.

Conflicts of Interest: The authors declare no conflict of interests.

\section{References}

[1] J. Burgess and J. Connell, "Temporary work and human resources management: issues, challenges and responses," Pers. Rev., vol. 35, no. 2 , pp. 129-140, Mar. 2006.

[2] A. Pollert and A. Charlwood, "The vulnerable worker in Britain and problems at work," Work. Employ. Soc., vol. 23, no. 2, pp. 343-362, 2009.

[3] E. Preenen,P., Verbiest, S., Vianen, A. e Wijk, "Informal learning of temporary agency workers in low-skill jobs : The role of self-profiling, career control, and job challenge," Career Dev. Int., vol. 20, no. 4, pp. 339-362, 2015.

[4] T. T. Selvarajan, J. Slattery, and D. Y. Stringer, "Relationship between gender and work related attitudes: a study of temporary agency employees," J. Bus. Res., vol. 68, no. 9, pp. 1919-1927, 2015. 
[5] S. A. Way, D. P. Lepak, C. H. Fay, and J. W. Thacker, "Contingent workers' impact on standard employee withdrawal behaviors: Does what you use them for matter?," Hum. Resour. Manage., vol. 49, no. 1, pp. 109138, Jan. 2010.

[6] A. S. Boyce, A. M. Ryan, A. L. Imus, and F. P. Morgeson, "“Temporary Worker, Permanent Loser?'A Model of the Stigmatization of Temporary Workers," J. Manage., vol. 33, no. 1, pp. 5-29, 2007.

[7] J. Michie and M. Sheehan-Quinn, "Labour market flexibility, human resource management and corporate performance,” Br. J. Manag., vol. 12, no. 4, pp. 287-306, 2001.

[8] J. Barney, "Firm Resources and Sustained Competitive Advantage," J. Manage., vol. 17, no. 1, pp. 99-120, 1991.

[9] J. B. Barney and D. N. Clark, "Resource-based theory: Creating and sustaining competitive advantage," Long Range Plann., vol. 3, no. 24, pp. 32-39, 1991.

[10] K. M. Eisenhardt, "Building Theories from Case Study Research," vol. 14, no. 4, pp. 532-550, 1989.

[11] J. T. Mahoney, "The management of resources and the resource of management,” J. Bus. Res., vol. 33, no. 94, pp. 91-101, 1995.

[12] D. J. Teece, G. Pisano, and A. Shuen, “MANAGEMENT," Strateg. Manag. J., vol. 18, no. 7, pp. 509-533, 1997.

[13] M. Augier and D. J. Teece, "Dynamic Capabilities and the Role of Managers in Business Strategy and Economic Performance," Organ. Sci., vol. 20, no. 2, pp. 410-421, 2009.

[14] L.-Y. Wu, "Entrepreneurial resources, dynamic capabilities and start-up performance of Taiwan's high-tech firms," J. Bus. Res., vol. 60, no. 5, pp. 549-555, 2007.

[15] K. M. Eisenhardt and A. J. Martin, "Dynamic capabilities: what are they?," Strateg. Manag. J., vol. 21, pp. 1105-1121, 2000.

[16] V. S. Katkalo, C. N. Pitelis, and D. J. Teece, "Introduction : On the nature and scope of dynamic capabilities," vol. 19, no. 4, pp. 1175-1186, 2010.

[17] A. J. Kraaijenbrink, J., Spender, J. C., \& Groen, "The resource-based view : A review and assessment of its critiques.," J. Manage., vol. 36, no. 1, pp. 349-372, 2010.

[18] A. . Martín-Artiles, O. . Molina, and P. . Carrasquer, "Uncertainty and attitudes pro-redistributive: Labour market and welfare models in Europe [Incertidumbre y actitudes pro-redistributivas: mercados de trabajo y modelos de bienestar en Europa]," Polit. y Soc., vol. 53, no. 1, pp. 187$215,2016$. 
[19] I. Kovács, "Emprego flexível em Portugal 1," Sociologias, vol. 6, no. 12, pp. 32-67, 2004.

[20] S. G. Helfat, C.E.; Finkelstein, S., Mitchell, W., Peteraf, M.A., Singh, H., Teece, D.J., Winter, Dynamic capabilities: Understanding strategic change in organizations. 2007.

[21] S. G. Winter, "Understanding dynamics capabilities," Strateg. Manag. J., vol. 24, pp. 991-995, 2003.

[22] F. Moscone, E. Tosetti, and G. Vittadini, "The impact of precarious employment on mental health: The case of Italy," Soc. Sci. Med., vol. 158, 2016.

[23] G. S. F. Bruno, F. E. Caroleo, and O. Dessy, "Temporary contracts and young workers ' job satisfaction in Italy," 2013.

[24] R. Bardazzi and S. Duranti, "Atypical work: a threat to labour productivity growth? Some evidence from Italy,” Int. Rev. Appl. Econ., vol. 30, no. 5, pp. 620-643, 2016.

[25] A. Bagnai and C. A. Mongeau Ospina, "Monetary integration vs. real disintegration: single currency and productivity divergence in the euro area\#,”J. Econ. Policy Reform, vol. 21, no. 4, pp. 353-367, 2018.

[26] T. Boeri, "Institutional Reforms and Dualism in European Labor Markets," Elsevier, 2011.

[27] A. Bugarin, "Linking Welfare Recipients to Jobs: The Role of Temporary Help Agencies," 1998.

[28] T. Kyyrä, "Partial unemployment insurance benefits and the transition rate to regular work," Eur. Econ. Rev., vol. 54, no. 7, pp. 911-930, 2010.

[29] A. L. Booth, M. Francesconi, and J. Frank, “Temporary jobs: Stepping stones or dead ends?,” Econ. J., vol. 112, no. 480, pp. F189-F213, 2002.

[30] M. . de Graaf-Zijl, G. J. . c d e f van den Berg, and A. . Heyma, "Stepping stones for the unemployed: The effect of temporary jobs on the duration until (regular) work," J. Popul. Econ., vol. 24, no. 1, pp. 107-139, 2011.

[31] D. Lane, J., Mikelson, K. S., Sharkey, P., \& Wissoker, "Pathways to Work for Low- Income Workers : The Effect of Work in the Temporary Help Industry," J. Policy Anal. Manag., vol. 22, no. 4, pp. 581-598, 2003.

[32] M. de Graaf-Zijl, G. J. van den Berg, and A. Heyma, "Stepping stones for the unemployed: The effect of temporary jobs on the duration until (regular) work," J. Popul. Econ., vol. 24, no. 1, pp. 107-139, 2011.

[33] M. Gerfin and M. Lechner, "a Microeconometric Evaluation of the Active Labour Market Policy in Switzerland *," vol. 112, pp. 854-893, 2002. 
[34] H. A. Costa, "Desafios e dilemas da sua aplicação," Rev. Crit. Cienc. Sociais, vol. 86, pp. 123-144, 2009.

[35] F. Ernesto, C. Antonella, R. Paolo, and C. Quintano, Being NEET in Europe Before and After the Economic Crisis : An Analysis of the Micro and Macro Determinants, vol. 149, no. 3. Springer Netherlands, 2020.

[36] V. Pulignano and N. Doerflinger, "A head with two tales: trade unions' influence on temporary agency work in Belgian and German workplaces," Int. J. Hum. Resour. Manag., vol. 24, no. 22, pp. 4149-4165, 2013.

[37] Y.-F. . Chen and M. . Funke, "Threshold effects of dismissal protection regulation and the emergence of temporary work agencies," Stud. Nonlinear Dyn. Econom., vol. 13, no. 4, 2009.

[38] N. De Cuyper, J. De Jong, H. De Witte, K. Isaksson, T. Rigotti, and R. Schalk, "Literature review of theory and research on the psychological impact of temporary employment: Towards a conceptual model," Int. J. Manag. Rev., vol. 10, no. 1, pp. 25-51, 2008.

[39] H. Beynon, Managing employment change: The new realities of work. 2002.

[40] C. E. Connelly and D. G. Gallagher, "Emerging Trends in Contingent Work Research,” J. Manage., vol. 30, no. 6, pp. 959-983, 2004.

[41] G. R. Oldham and Y. Fried, "Job design research and theory: Past, present and future,” Organ. Behav. Hum. Decis. Process., vol. 136, pp. 20-35, 2016.

[42] F. J. Carre, Nonstandard Work: The Nature and Challenges of Changing Employment Arrangements, vol. 1st. 2000.

[43] C. E. Helfat, "Know-how and Asset Complementarity and Dynamic Capability Accumulation: The Case of R\&D.," Strateg. Manag. J., vol. 18, no. 5, pp. 339-360, 1997.

[44] D. Kopycińska and E. Kryńska, "The precariat in the labour market in Poland - social and economic aspects," J. Int. Stud., vol. 9, no. 2, pp. 7989, 2016.

[45] A. Skibiński, "Assessment of the Degree Ageing Labour Force for Example of Poland and Slovakia," Eur. J. Sustain. Dev., vol. 7, no. 3, pp. 473-482, 2018.

[46] M. Estevao and S. Lach, "Measuring Temporary Labor Outsourcing in U.S. Manufacturing,” Natl. Bur. Econ. Res. Work. Pap. Ser., vol. No. 7421, no. October, 1999.

[47] V. . Osuna and J. I. . García-Pérez, "On the Effectiveness of Short-time Work Schemes in Dual Labor Markets," Econ., vol. 163, no. 3, pp. 323$351,2015$. 
[48] E. Kopycińska, D., \& Kryńska, "Employment of the disabled in the EU in the framework of Europe 2020 Strategy," J. Int. Stud., vol. 8, no. 3, pp. 919, 2015.

[49] J. B. Barney, "Strategic Factor Markets: Expectations, Luck, and Business Strategy," Manage. Sci., vol. 32, no. 10, pp. 1231-1241, Oct. 1986.

[50] J. Barney, M. Wright, and D. J. Ketchen, "The resource-based view of the firm: ten years after 1991," Journal of Management, vol. 27, no. 6. pp. 625-641, 2001.

[51] Y. Lin and L. Y. Wu, "Exploring the role of dynamic capabilities in firm performance under the resource-based view framework," J. Bus. Res., vol. 67, no. 3, pp. 407-413, 2014.

[52] V. Pulignano, G. Meardi, and N. Doerflinger, "Trade unions and labour market dualisation: A comparison of policies and attitudes towards agency and migrant workers in Germany and Belgium," Work. Employ. Soc., vol. 29, no. 5, 2015.

[53] H. Zhou, R. Dekker, and A. Kleinknecht, "Flexible labor and innovation performance: evidence from longitudinal firm-level data," Ind. Corp. Chang., vol. 20, no. 3, pp. 941-968, 2011.

[54] T. Vlandas, "The Politics of Temporary Work Deregulation in Europe: Solving the French Puzzle," Polit. Soc., vol. 41, no. 3, pp. 425-460, 2013.

[55] B. Koene and S. (Shaz) Ansari, "Institutional change and the multinational change agent: A study of the temporary staffing industry in Spain," J. Organ. Chang. Manag., vol. 24, no. 4, pp. 511-531, 2011.

[56] K. Golsch, "Employment flexibility in spain and its impact on transitions to adulthood," Work. Employ. Soc., vol. 17, no. 4, pp. 691-718, 2003.

[57] J. Marôco, Análise estatística com o SPSS Statistics. 2014.

[58] M. H. Pestana and J. N. Gageiro, “ANÁLISE DE DADOS PARA CIÊNCIAS SOCIAIS A Complementaridade do SPSS 6 a EDIÇÃO Revista, Atualizada e Aumentada MARIA HELENA PESTANA JOÃO NUNES GAGEIRO," no. September, pp. 1-2, 2014.

[59] E. Kopycińska, D., \& Kryńska, "Employment of the disabled in the EU in the framework of Europe 2020 Strategy," J. Int. Stud., vol. 8, no. 3, pp. 9$19,2015$.

[60] V. Pulignano and N. Doerflinger, "A head with two tales: Trade unions' influence on temporary agency work in Belgian and German workplaces," Int. J. Hum. Resour. Manag., vol. 24, no. 22, 2013. 